УДК $553.98 ; 550.4 ; 571.12$

\title{
ГЕНЕЗИС УГЛЕВОДОРОДОВ ЮРСКОГО И ДОЮРСКОГО КОМПЛЕКСОВ ЧИСТИННОГО МЕСТОРОЖДЕНИЯ (ЗОНА КОЛТОГОРСКО-УРЕНГОЙСКОГО ПАЛЕОРИФТА)
}

\author{
Коржов Юрий Владимирович',
} ykor1962@mail.ru

Лобова Галина Анатольевна, lobovaga@tpu.ru

Исаев Валерий Иванович',1, isaevvi@tpu.ru

\section{Стариков Андрей Иванович', a_starikov@ugrasu.ru}

\author{
Кузина Марина Яковлевна', \\ m_kuzina@ugrasu.ru
}

\author{
Орлов Сергей Анатольевич', \\ yunitov@mail.ru \\ 1 Институт нефти и газа Югорского государственного университета, \\ Россия, 928011, г. Ханты-Мансийск, ул. Чехова, 16. \\ 2 Национальный исследовательский Томский политехнический университет, \\ Россия, 634050, г. Томск, пр. Ленина, 30.
}

Определяется генезис углеводородов в юрском и доюрском комплексах Чистинной группы месторождений, расположенных в пределах развития Колтогорско-Уренгойского палеорифта. Исследование актуально для обоснования стратегии поисков нефтегазовых залежей с учетом тектоники фундамента Западно-Сибирской плиты.

Цель: установление «главного источника» углеводородов залежей юрского и доюрского горизонтов на рифтогенных участках фундамента.

Объекты и методы исследования. Исследован керновый материал юрского и доюрского комплексов продуктивных и непродуктивной скважин Чистинной группы месторождений Вартовского нефтегазоносного района. Литолого-петрографическая характеристика выполнена на основе оптической микроскопии. Методами органической геохимии, хромато-масс-спектрометрии определено содержание в породе подвижных углеводородов, включая ряды н-алканов, н-алкилбензолов, компонентов рядов нафталина и фенантрена.

Результаты и выводы. Построена геохимическая модель меж- и внутрипластовой миграции углеводородов. Состав углеводородов верхней части юрского разреза указывает, что залежи нефти в васюганской свите (пласт Ю') формировались в результате эмиграции углеводородов из аргиллитов баженовской и георгиевской свит. Органическое вещество пород фундамента и низов юрского разреза отличается от вышележащих отложений по молекулярному и групповому составу углеводородов и, вероятно, не участвовало в заполнении верхнеюрских ловушек. Триасовые вулканиты неблагоприятны для образования резервуаров УВ, пустоты залечены вторичными минералами из-за развитых гидротермальных процессов и отсутствия значимой дизьюнктивной тектоники, прогноз заполнения ловушек коры выветривания из вышележащего «юрского источника» маловероятен. В доюрском основании из органического вещества палеозойского генезиса могут сформироваться мелкие залежи. В рассматриваемой зоне континентального палеорифта реализуется классический депрессионный режим нефтегазообразования.

\section{Ключевые слова:}

Юрский и доюрский комплексы, литология, «главный источник» углеводородов, оптическая микроскопия и методы органической геохимии, геохимическая модель миграции и аккумуляции углеводородов рифтогенных участков Западно-Сибирской плиты.

\section{Введение}

Нефтеносность фундамента Западно-Сибирской плиты (ЗСП) подтверждена на всех крупных сводовых структурах. Залежи обнаружены в интервалах доюрского фундамента и коры выветривания Сургутского, Александровского, Красноленинского сводов. Распределение месторождений неравномерно, в большинстве промышленные дебиты из верхних горизонтов фундамента низкие или средние, в пределах $10 \ldots 50 \mathrm{~m}^{3} /$ сут $[1,2]$, но на отдельных участках получены фонтанирующие притоки, до $400 \ldots 600 \mathrm{~m}^{3}$ /сут - Ханты-Мансийское месторождение [3]. Неравномерная концентрация запасов в доюрских отложениях ЗСП обусловлена, вероятно, различными механизмами аккумуляции углеводородов (УВ) или различными условиями генерации нефти и газа из рассеянного осадочного органического вещества (OB).

Согласно стратиграфо-тектоническим моделям $[4,5]$, доюрское основание ЗСП является сложным 
и гетерогенным тектоническим сооружением. Здесь представлены как депрессионные бассейновые зоны, так и зоны с признаками столкновения литосферных плит, а также протяженная с севера на юг разветвленная пермь-триасовая грабен-рифтовая система с усиленным геодинамическим режимом недр [6].

Все указанные тектонические структуры, в соответствии с идеями тектоники плит и плюмовой тектоники [7, 8], в пределах ЗСП являются потенциально нефтеносными. В депрессионных зонах реализуется классическая осадочно-миграционная модель нефтеобразования [9, 10], предполагающая наличие нефтематеринских свит и резервуаров. В участках коллизии плит или рифта рядом исследователей признается многофакторность и нелинейность процесса генезиса нефти и газа. В пределах рифтовых участков, где высокий тепловой поток, углеводородный флюид может генерироваться как непосредственно ОВ осадочных комплексов бассейнов рифтогенного типа, так и за счет неорганического синтеза $[11,12]$. В районах столкновения литосферных плит создаются наиболее благоприятные условия нефтегазообразования за счет максимальной раскрытости недр и обмена флюидами поверхностных и глубинных сфер [7, 13].

Такой многофакторный и многовариантный научный подход $\mathrm{k}$ вопросу происхождения залежей нефти и газа мало применим в прогнозно-оценочных и поисковых работах на нефть. На практике поисков в доюрских комплексах ЗСП геологи и геофизики выстраивают стратегию на критериях «зон разуплотнения» и четко определенной концепции «главного источника». Для поисков «зон разуплотнения» практически всегда применяется сейсморазведка $[1,14]$ и рекомендуется гравиразведка [15-17]. А вот концепция «главного источника» дискутируется в двух вариантах: 1) глубинная нефть формирует залежи палеозоя, триаса и юрского комплекса $[18,19]$; 2) нефть - продукт материнских юрских отложений и заполняет резервуары триаса и палеозоя [20-23]. Отсюда следует сильная неоднозначность рекомендаций относительно стратегии поисков в доюрском основании, да и в юрском комплексе.

Ранее [24, 25], для уточнения представлений о генезисе углеводородов в областях устойчивых погруженных кристаллических массивов, авторами предпринимались геохимические, геофизические и литолого-петрографические исследования юрского и доюрского комплексов в пределах Рогожниковской группы месторождений (рис. $1, \mathrm{~A}$, Красноленинский свод). Методами геоплотностного моделирования, оптической микроскопии и органической геохимии были выявлены и охарактеризованы две зоны внутрипластовой и межпластовой миграции углеводородов. Одна - в интервале верхнеюрских отложений, вторая - низы юрского разреза и верхний интервал триаса. Обоснован приток углеводородов в триасовые породы из низов тюменской свиты.
Текущее исследование направлено на внесение ясности в концепцию «главного источника» залежей УВ на одном из рифтогенных участков ЗСП Чистинной группы месторождений (рис. 1), расположенной в районе локального растяжения в западном борту Колтогорско-Уренгойского палеорифта [26]. Нужно отметить, что ранее в рассматриваемом и смежных районах проведен большой объем генетических исследований сырой нефти по составу ароматических углеводородов [27], по составу и количеству стеранов, терпанов и алканов [28].

Нами исследовано послойное распределение таких классических геохимических индикаторов $[29,30]$, как ряды н-алканов и н-алкилбензолов (н-АБ) в керне пород юрского и доюрского комплексов скважин ЗЧ501 и СЧ480, продуктивных в верхнеюрских отложениях. Сравнение выполнено с данными исследования керна верхнеюрских отложений непродуктивной (фоновой) скважины ЮЧ511. Фоновая скважина находится в непосредственной близости от контура нефтеносности, но без признаков нефтепроявления.

\section{Нефтегеологическая характеристика объекта исследований}

В тектоническом отношении Чистинный участок приурочен к восточному борту Юганской мегавпадины [31]. Он охватывает Северо-Чистинную и Западно-Чистинную антиклинальные складки. Согласно нефтегеологическому районированию, Чистинный участок объединяет Чистинное, Северо-Чистинное, Южно-Чистинное и Западно-Чистинное месторождения Вартовского нефтегазоносного района. Залежи нефти здесь приурочены к нижнеюрскому, верхнеюрскому и нижнемеловому (ачимовская пачка) нефтегазоносным комплексам (НГК). Залежей в доюрском НГК, индивидуально идентифицированных, в пределах исследуемого участка пока не обнаружено. Однако нужно отметить факт совместного испытания [32], включающего интервал пласта $Ю_{11}$ в нижнеюрском НГК и верхнюю часть палеозоя, давшего дебит нефти $38 \mathrm{~m}^{3}$ /сут. Но и при отдельном опробовании этого нижнеюрского пласта получен приток нефти $5,8 \mathrm{~m}^{3} /$ сут.

Верхнеюрский НГК включает залежи в пластах горизонта Ю. В пределах участка выявлена невыдержанность по площади песчаного резервуара. Залежь нефти литологически экранированного типа занимает западное крыло Северо-Чистинного структурного мыса, она включает скопления нефти, открытые скважинами.

На Западно-Чистинном поднятии бурением поисковой скважины 501 открыта залежь нефти в пласте $\mathrm{F}_{1}{ }^{1}$ с эффективной нефтенасыщенной толщиной пласта 9,2 м. Залежь пластово-сводовая, осложненная в южной части литологическим экраном. По величине извлекаемых запасов месторождение относится к категории средних, по геологическому строению - к сложным. 
Для изучения нефтегазоносности фундамента и юрских отложений выбраны скважины (рис. 1, Б), геохимические и литолого-петрографические особенности керна которых позволят внести большую ясность в концепцию «главного источника» УВ в доюрском основании ЗСП - это Северо-Чистинная 480, Западно-Чистинная 501 и Южно-Чистинная 511 (законтурная), расположенные в пределах Чистинного участка.

\section{Методика исследований}

Керновый материал продуктивной скважины ЗЧ501 (11 образцов) включает породу в пределах интервалов развития юрского и доюрского нефтегазоносных комплексов. В продуктивной СЧ480 (11 образцов) и фоновой ЮЧ511 (3 образца) исследованиями охвачен только юрский комплекс, включая георгиевскую, васюганскую и частично тюменскую свиты.
Минеральный состав пород изучен на поляризационном микроскопе ПОЛАМ 2-213М. Гранулометрический анализ образцов из доюрского комплекса выполнен также в шлифах, оптическим методом. Далее для специальных геохимических исследований [24] пробы были измельчены на лабораторном оборудовании до зернения не более 2 мм.

Выделение слабополярных углеводородов выполняли двойной холодной экстракцией смесью растворителей н-гексан: хлороформ (80:20 об. \%). Данный растворитель избирательно экстрагирует углеводороды рядов н-алканов $\mathrm{C}_{9-40}$, алкилбензолов $\mathrm{C}_{9-33}$, нафталинов $\mathrm{C}_{10-13}$, фенантренов $\mathrm{C}_{14-16}$, другие малополярные вещества, почти не захватывая смолистые компоненты битумоида пород. Анализ экстрактов проведен на хромато-масс-спектрометре PerkinElmer Clarus 500MS.

Оиенка полноты выделения индивидуальных веществ и групп углеводородов выполнена на кон-

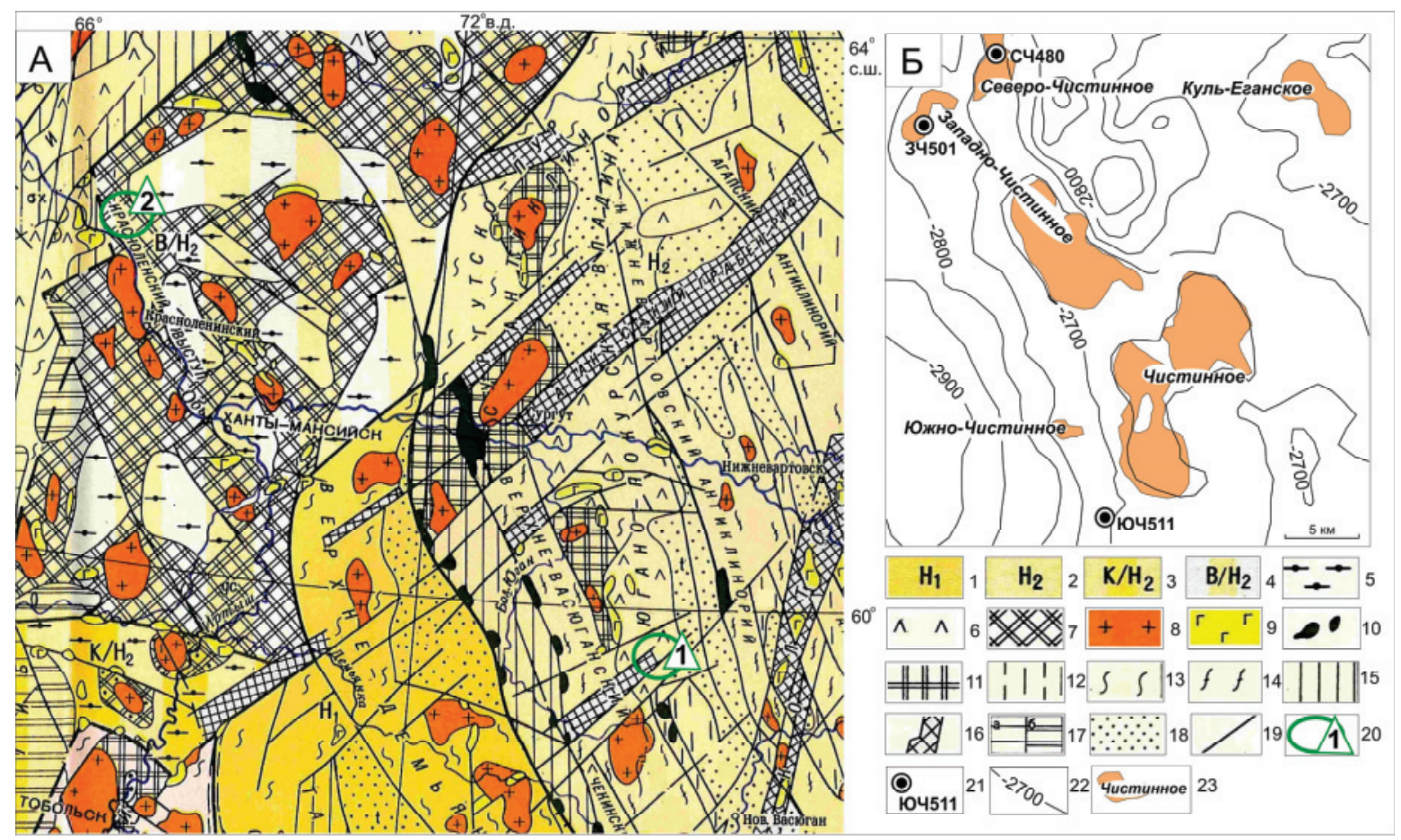

Pис.1. Обзорная схема исследования на тектонической основе [26] (А) и положение исследуемых скважин на структурной карте по отражающему горизонту Б (Б). К схеме А: (1-4) - возраст стабилизации области: 1 - раннегериинский, 2 - позднегериинский, 3 - докарельской и карельской складчатости, 4 - байкальской складчатости, 5 - наложенные впадины и прогибы в пределах устойчивых массивов, 6 - раннемезозойские впадины и грабены в пределах каледонид и гериинид, 7 - выступы-горсты байкалид, 8 - гранитоиды, 9 - базиты, 10 - ультрабазиты, 11 - ядра антиклинориев байкалид, 12 - межгорные прогибы, 13 - унаследованные антиклинорные зоны, 14 - инверсионные антиклинорные зоны, 15 - унаследованные синклинорные зоны, 16 - раннемезозойские грабен-рифты, 17 - краевые прогибы, 18 - межгорные прогибы и впадины, 19 - разломы, 20 - район исследований: Чистинная группа месторождений (1), Рогожниковская группа месторождений (2). К положению Чистинных скважин (Б): 21 - исследуемая скважина и ее индекс; 22 - изогипсы кровли юрских отложений (м); 23 - месторождение УВ и его название

Fig. 1. Overview scheme of the study on tectonic basis [26] (A) and the position of the wells on the structural map of the reflecting horizon $B$ ( 5$)$. To the scheme A: (1-4) - age of stabilization of the region: 1 - early Hercynian, 2 - late Hercynian, 3 - pre-Karelian and Karelian orogeny, 4 - Baikal orogeny, 5 - imposed depressions and troughs in stable landmasses, 6 - early Mesozoic depressions and grabens within the caledonides and hercynides, 7 - horsts of baikalides, 8 - granitoids, 9 - mafics, 10 - ultrabasic rocks, 11 - cores of anticline of baikalides, 12 - intermountain troughs, 13 - inherited anticlinoria zones, 14 - inversion anticlinoria zones, 15 - inherited synclinoria zones, 16 - early Mesozoic graben-rift, 17 - fore deeps, 18 - intermountain troughs and depressions, 19 - faults, 20 - area of research: Chistinnaya group of fields (1), Rogozhnikovsky group of fields (2). To the position of wells of Chistinnoe (B): 21 - the investigated well and its index; 22 - isoheights of the superface of Jurassic sediments $(\mathrm{m}) ; 23$ - oil field and its name 
трольном образце песчаника керна скважины 7 Борового месторождения [33]. Исходное содержание углеводородов в образце было определено хромато-масс-спектрометрией, после исчерпывающей экстракции хлороформом в аппарате Сокслета, на уровне $0,831 \mathrm{мг} /$ кг н-алканов $\mathrm{C}_{8-35}, 0,0082 \mathrm{мг} /$ кг налкилбензолов $\mathrm{C}_{8-32}, 0,0173$ мг/кг алкилнафталинов $\mathrm{C}_{10-12}$ и алкилфенантренов $\mathrm{C}_{14-15}$. При однократной экстракции смесью н-гексан: хлороформ (80:20 об.) с образца песчаника было экстрагировано 80-90\% указанных углеводородов, до триаренов включительно. После экстракции по второй ступени указанные соединения не обнаруживаются методом хроматографии в остаточном битумоиде при его исчерпывающей экстракции хлороформом в аппарате Сокслета.

Точность аналитических результатов при повторных анализах образцов керна глубоких скважин месторождений Боровое (скв. Б7), Южно-Чистинное (скв. ЮЧ511), Северо-Чистинное (скв. СЧ480), Рогожниковское (скв. Р765, Р718) в условиях прецизионности эксперимента, составляет [24]:

- для диапазона концентраций 0,005...0,010 мг/кг на уровне $\pm 32-33 \%$;

- для концентрации 0,015 мг/кг - на уровне $\pm 30 \%$;

- для концентрации 1,30 мг/кг - на уровне $\pm 20 \%$.

Минимальный предел обнаружения (с точностью определения не выше $\pm 35 \%$ отн.) составляет 0,005...0,010 мг/кг. При определении меньших концентраций (1...5 мкг/кг) разброс значений, по предварительным оценкам, возрастает до $50 \%$.

Выбор групn углеводородов для выполнения сравнительных исследований следующий. Учитывалось, что керн хранился в течение ряда лет в открытом состоянии в специальных условиях кернохранилища АУ «НАЦ РН им. В.И. Шпильмана» (г. Ханты-Мансийск). Поэтому в качестве информативных показателей состава органического вещества принято к рассмотрению содержание в породе рядов н-алканов $\mathrm{C}_{9-40}$ и н-алкилбензолов $\mathrm{C}_{8-34}$, наиболее устойчивых к окислению и выветриванию [34, 35].

\section{Литолого-петрографическое исследование пород доюрского и юрского комплексов}

Разрез доюрских пород представлен только в скважине ЗЧ501. Здесь вскрыта триасовая толща на глубине 3390 м и прослежена до 3500 м. По скважине отобрано 11 образцов: 7 из доюрского комплекса, 2 из нижнеюрских и 2 из верхнеюрских отложений. Для 10 из них сделаны петрографические шлифы. В скважинах СЧ480 и ЮЧ511 керном охарактеризована только юрская часть разреза. Отобрано для исследований 11 и 3 образца из нижнеюрский и верхнеюрских отложений, соответственно. На рис. 2 приводятся фотографии шлифов.
Породы триасового колплекса сложены вулканогенно-осадочными туфо-базальтами. Верхний рассматриваемый интервал (3425 ...3431,3 м) представлен сильно изменёнными туфами предположительно основного состава. В шлифах (рис. 2, a) наблюдаются кристаллокласты плагиоклаза, почти нацело замещённые карбонатом и соссюритом, и кристаллокласты темноцветных минералов, замещённые хлоритом и карбонатом.

Матрикс породы интенсивно изменён, вторичные минералы - карбонат, хлорофеит, глинистые и рудные минералами, в выполнении участвуют гидроокислы железа. $10 . . .35 \%$ породы занимают миндалины (рис. 2, б), размер которых колеблется от 0,5 мм до 2 см. Строение зональное, часто краевые части выполнены кальцитом, далее идёт хлоритовая оторочка и в центре - халцедон. В наиболее крупных из миндалин центральные части заполнены кристаллическим кварцем. Имеются залеченные трещины мощностью до 5 мм. Трещинное пространство выполнено карбонатом и халцедоном с примесью слоистых агрегатов. В отдельных миндалинах и по трещинам наблюдается битуминозное вещество (образец 10 ЗЧ501). В слое $3439 . . .3441$ м залегают туфо-базальты темно-серого цвета. В шлифах видно, что породы практически не содержат порфировых вкрапленников, основная масса интенсивно изменена, большое содержание рудных минералов и гидроокислов железа. Миндалины редки, размером до $1 \mathrm{cм}$, имеют зональное строение, выполнены карбонатом, халцедоном, сапонитом. Интервал $3497,6 \ldots 3499$ м сложен красно-коричневыми миндалекаменными туфами. Миндалины занимают до 50 \% породы, размером до 2 см, краевые части сложены крустификационным кальцитом, центральные - сферолитами халцедона (рис. 2, б).

Таким образом, доюрская часть разреза в 501 скважине сложена типично грабен-рифтовой ассоциацией пород вулканогенно-осадочного генезиса, претерпевших сильные гидротермальные изменения. Первоначально основной состав породы, в результате гидротермальной проработки, оказался значительно карбонатизированым, хлоритизированым, гематитизированым. Кроме того, часто поровое пространство и трещины выполнены битуминозным веществом.

Необходимо отметить, что такие породы, как туфы основного состава, обладают благоприятными для образования резервуаров УВ свойствами они содержат достаточное количество пустот, при гидротермальной проработке сохраняют крепкий минеральный каркас. Но в данном случае породы не трещиноватые, имеющиеся миндалины и трещины залечены вторичными минералами, то есть из-за сильно развитых гидротермальных процессов и отсутствия сколько-нибудь значимой дизъюнктивной тектоники свободного порового пространства в триасовых вулканитах не образовалось. 


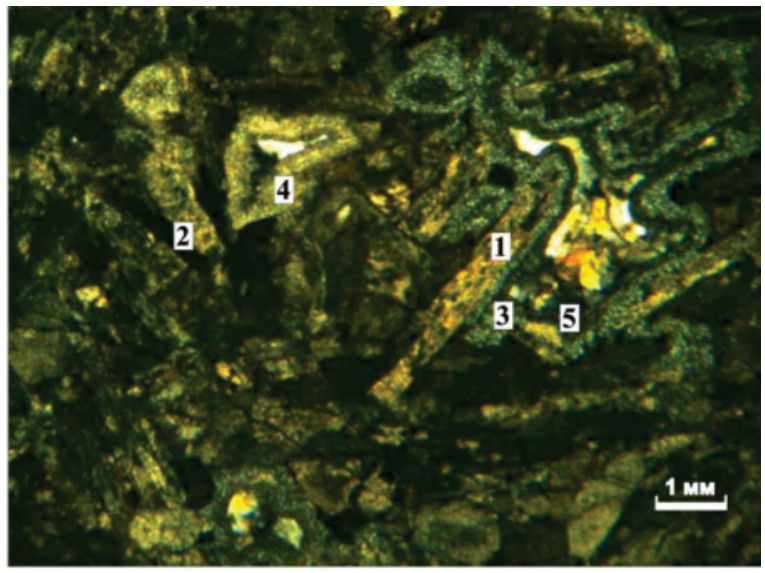

$a / a$

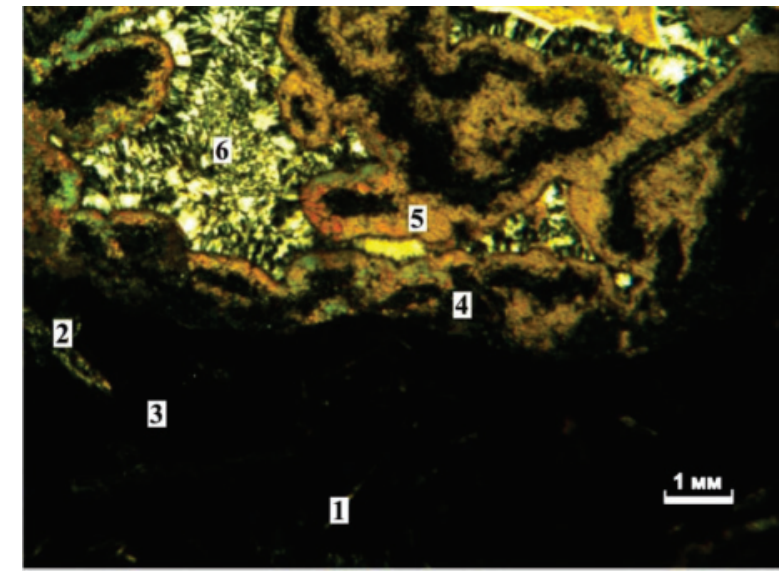

$\sigma / b$

Puc. 2. а) Образеи 7 ЗЧ501. Глубина 3425,8 м. Сильно изменённый вулканит основного состава. Кристаллокласты плагиоклаза (1) до 5 мл длиной почти полностью замещены вторичныли минералами: кальцитол, соссюритом (2). Стекло замещено хлорофеитол, темноиветы - боулингитол, гетитом. Миндалины зональные, разлер от 0,5 мл до 1 см, краевые участки выполнены цеолитали (3) либо крустификационным кальиитом (4), далее идёт хлоритовая зона (5), центральные части выполнены халиедоном или кварием; б) Образеи 11 ЗЧ501. Глубина 3499 м. Сильно изленённый вулканит основного состава. Основная масса сложена бурым вулканическил стеклом (1), замещённыл агрегатол карбоната, халиедона (2), глинистых образований (3), гидроокислами железа (4). Присутствуют миндалины зонального строения, хлоритовая оторочка, затем карбонатная зона (5) и в центре халиедон или квари (6). (Николи Х)

Fig. 2. a) Core sample 7 ZCh501. Depth $3425,8 \mathrm{~m}$. Strongly altered mafic volcanite. Plagioclase (1) up to $5 \mathrm{~mm}$ long, almost completely replaced by secondary minerals: calcite, saussurite (2). Glass replaced with peach, bowlingite, goethite. Amygdules are zonal, size from $0,5 \mathrm{~mm}$ to $1 \mathrm{~cm}$, the edge areas are made of zeolites (3) or calcite (4), then there is a chlorite zone (5), the central parts are made of chalcedony or quartz; b) Sample 11 ZCh501. Depth $3499 \mathrm{~m}$. Strongly altered mafic volcanite. The groundmass is composed of brown volcanic glass (1), replaced by a unit of carbonate, chalcedony (2), clay formations (3), iron hydroxides (4). There are amygdules of zonal structure, chlorite, then there is carbonate zone (5) and in the center there is chalcedony or quartz (6). (Crossed nicols)

Юрская систела (J) представлена нижним, средним и верхним отделами. Нижнеюрский отдел $\left(J_{1}\right)$ образует терригенную толщу котухтинской свиты $\left(J_{1} t\right)$. Нижняя подсвита, с песчаным пластом $Ю_{11}$ в основании перекрыта глинистой и битуминозной тогурской пачкой. Глинистая радомская пачка, с включениями битума, перекрывает песчано-гравелитовый пласт $Ю_{10}$. В образцах скважины ЗЧ501 котухтинская свита представлена среднезернистыми, слабослюдистыми, кварцевыми песчаниками с глинистым цементом, слабо серицитизированными светло-серыми алевролитами с включениями растительного детрита, а также слабослюдистыми серыми аргиллитами с углистым материалом.

Среднеюрский отдел $\left(J_{2}\right)$ сложен породами континентального генезиса и обособляется в тюленскую свиту ( $\left.{ }_{2} a-b-b t\right)$. Происходит тонкое переслаивание песчано-алевролитовых и глинистых пачек с прослоями углей.

Верхнеюрский отдел $\left(J_{3}\right)$, промышленно нефтеносный на Чистинной площади, формируется в глубоководно-морских и прибрежно-мелководных условиях. В состав келловей-титонского комплекса пород входят отложения васюганской, георгиевской и баженовской свит.

В нижней части васюганской свиты $\left(J_{2} k-J_{3} 0\right)$, на наиболее погруженных участках, в основании развит базальный песчано-алевролитовый пласт $\mathrm{F}_{2}{ }^{0}$ (пахомовская пачка). В скважине ЗЧ501 васю- ганская свита (пласт $Ю_{2}$ ) сложена тёмно-серыми аргиллитами с тонкими прожилками углистого материала и включениями растительных остатков, а также слабо сцементированными глинистым цементом мелкозернистыми, кварцевыми, серыми песчаниками. Эти породы сформировались в прибрежно-мелководных и морских условиях. В верхней подсвите происходит переслаивание песчаников, алевролитов и аргиллитов с линзами углей, разделяющих горизонт $Ю_{1}$ на отдельные пласты $\left(Ю_{1}{ }^{1}, Ю_{1}{ }^{2}, Ю_{1}{ }^{3}\right)$. Толщина свиты в скважине ЗЧ501 достигает 105 м.

Выше по разрезу залегает георгиевская свита $\left(J_{3} k m-t t\right)$ мощностью $1 . . .6$ м. Отложения представлены образцами скважин СЧ480 и ЮЧ511(фоновая) - аргиллитами темно-серыми, почти черными со слабым зеленоватым оттенком. Свита перекрывается буровато-черными карбонатно-кремнистоглинистыми породами баженовской свиты $\left(J_{3} t t\right)$, сформировавшимися в морских условиях, богатыми органическим веществом сапропелевого типа.

\section{Анализ геохимических данных}

\section{для определения источника углеводородов}

Основным нефтеносным объектом в пределах юрского комплекса Чистинного участка является васюганская свита (горизонт $Ю_{1}$ ). Нефти по плотности легкие и средние, малосернистые и сернистые, содержание смол - $6 . . .10 \%$, парафинов - менее $3 \%$. 
Региональным флюидоупором являются массивные аргиллиты баженовской свиты, они же, возможно, являются основным источником УВ вышележащих ловушек ачимовской пачки. В пределах участка мощность баженовской свиты от 10 до $30 \mathrm{M}$.

Для оценки перспектив нефтеносности доюрского основания изучен состав ОВ пород юрского и триасового комплексов. В таблице приведены данные по содержанию в образцах н-алканов $\mathrm{C}_{9-40}$, алкилбензолов $\mathrm{C}_{9-33}$, суммарно ароматических углеводородов ( $\Sigma \mathrm{Ap})$, включая н-алкилбензолы, нафталины $\mathrm{C}_{10-13}$, фенантрены $\mathrm{C}_{14-15}$. В таблице также приведен расчетный геохимический параметр (П/Ф=пристан/фитан) обстановки осадконакопления [36-38]. На рис. 3,4 в разрезах скважин ЗЧ501 и СЧ480 представлено содержание в породе н-алканов и н-алкилбензолов, а также показаны их гомологические молекулярно-массовые распределения (MМР).

В разрезе скважин СЧ480 и ЗЧ501 концентрация идентифицированных УВ в верхах васюганской свиты варьирует от 2,6 до 42,9 мг/кг и достигает в аргиллитах георгиевской свиты 152 мг/кг (образец 1 СЧ480). Соотношение насыщенных и ароматических - обычное для нефти, с преобладанием насыщенных УВ (таблица). В низах васюганской и в отложениях тюменской свиты содержание УВ в среднем меньше - от 2,4 до 15,4 мг/кг. Отличительной особенностью аргиллитов данного интервала является высокая концентрация ароматических, их содержание 7,8...8,0 мг/кг сравнимо с содержанием насыщенных УВ - 5,5...7,6 мг/кг. Такой состав УВ характерен для континентальных

таблица. Х Характеристика органического вещества исследованного керна

Table. $\quad$ Characteristics of organic substance of the studied core

\begin{tabular}{|c|c|c|c|c|c|c|c|}
\hline \multirow{2}{*}{$\begin{array}{l}\text { № образца, порода } \\
\text { Sample no., rock }\end{array}$} & \multirow{2}{*}{$\begin{array}{c}\text { Свита, пласт } \\
\text { Suite, formation }\end{array}$} & \multirow{2}{*}{\begin{tabular}{|c|} 
Сумма \\
ОВ, мг/кг \\
Eorganic \\
substance, \\
$\mathrm{mg} / \mathrm{kg}$ \\
\end{tabular}} & \multicolumn{4}{|c|}{$\begin{array}{l}\text { Содержание в породе, мг/кг } \\
\text { Contents in the rock, mg/kg }\end{array}$} & \multirow{2}{*}{\begin{tabular}{|c|}
$\begin{array}{c}\text { Параметр состава } \\
\text { Composition parameter }\end{array}$ \\
П/Ф \\
$\mathrm{P} / \mathrm{S}$
\end{tabular}} \\
\hline & & & \begin{tabular}{|c|} 
н-алканов $\mathrm{C}_{9}-\mathrm{C}_{40}$ \\
n-paraffins
\end{tabular} & $\begin{array}{c}\mathrm{H}-\mathrm{Ab} \mathrm{C}_{8}-\mathrm{C}_{34} \\
\text { n-alkylbenzenes }\end{array}$ & $\begin{array}{l}\Sigma \mathrm{Ap} \\
\Sigma \mathrm{Ar}\end{array}$ & $\mid \begin{array}{c}\text { इидент. УВ } \\
\Sigma \mathrm{HC}\end{array}$ & \\
\hline \multicolumn{8}{|c|}{ Площадь Западно-Чистинная, скважина 501/Chistinnoe West, well 501} \\
\hline 1, аргиллит/argillite & $\begin{array}{c}\text { Васюганская }\left(\mathrm{J}_{2}\right) \mathrm{vs}, \\
\mathrm{Ю}_{2} \text { Vasyugan }\end{array}$ & 115,68 & 15,59 & 0,44 & 2,53 & 18,12 & 1,23 \\
\hline 2, песчаник/sandstone & vs, $Ю_{2}$ & 185,07 & 39,99 & 2,16 & 2,91 & 42,90 & 0,51 \\
\hline 3, песчаник/sandstone & $\begin{array}{c}\text { Котухтинская }\left(\mathrm{J}_{1}\right) \mathrm{kt}, \\
Ю_{10} \text { Kotukhtin }\end{array}$ & 33,17 & 2,67 & 0,05 & 0,10 & 2,77 & 0,95 \\
\hline 4, алевр./siltstone & kt, $Ю_{11}$ & 41,59 & 6,53 & 0,13 & 0,45 & 6,98 & 1,14 \\
\hline 5 , туф/tuff & $(\mathrm{T})$ & 35,53 & 4,16 & 0,07 & 0,13 & 4,29 & 0,92 \\
\hline 6, туф/tuff & $(\mathrm{T})$ & 23,52 & 2,85 & 0,05 & 0,07 & 2,92 & 1,04 \\
\hline 7 , туф/tuff & (T) & 41,17 & 3,39 & 0,05 & 0,08 & 3,47 & 1,05 \\
\hline 8 , туф/tuff & (T) & 33,88 & 4,07 & 0,08 & 0,10 & 4,17 & 0,68 \\
\hline 9, туф/tuff & (T) & 41,44 & 5,27 & 0,11 & 0,17 & 5,44 & 0,89 \\
\hline 10, туф/tuff & (T) & 21,78 & 0,67 & 0,01 & 0,02 & 0,69 & 0,76 \\
\hline 11, туф/tuff & $(\mathrm{T})$ & 63,38 & 4,84 & 0,10 & 0,16 & 5,00 & 0,99 \\
\hline \multicolumn{8}{|c|}{ Площадь Северо-Чистинная, скважина 480/Chistinnoe North, well 480} \\
\hline 1, аргиллит/argillite & $\begin{array}{c}\text { Георгиевская }\left(\mathrm{J}_{2}\right) \mathrm{gr} \\
\text { Georgiev }\end{array}$ & 2735,68 & 109,28 & 12,73 & 40,10 & 152,05 & 1,05 \\
\hline 2, песчаник/sandstone & $\begin{array}{c}\text { Васюганская }\left(\mathrm{J}_{2}\right) \mathrm{vs}, \\
Ю_{1} \text { Vasyugan }\end{array}$ & 142,54 & 4,64 & 0,40 & 1,46 & 6,10 & 1,24 \\
\hline 3, аргиллит/argillite & \multirow{7}{*}{ vs, $\wp_{1}$} & 265,75 & 2,63 & 0,15 & 0,85 & 3,48 & 1,52 \\
\hline 4, песчаник/sandstone & & 62,85 & 2,81 & 0,13 & 0,46 & 3,27 & 1,86 \\
\hline 5, аргиллит/argillite & & 56,11 & 2,42 & 0,06 & 1,21 & 3,63 & 1,88 \\
\hline 6, ap.+ ал./argillite + siltstone & & 134,70 & 3,69 & 0,08 & 3,95 & 7,64 & 2,67 \\
\hline 7, песчаник/sandstone & & 55,15 & 1,77 & 0,08 & 0,86 & 2,63 & 2,08 \\
\hline 8, аргиллит/argillite & & 144,22 & 5,47 & 0,16 & 7,96 & 13,43 & 3,75 \\
\hline 9, песчаник/sandstone & & 59,99 & 1,68 & 0,07 & 0,75 & 2,43 & 1,63 \\
\hline 10, ap. + п./argillite + sandstone & $\begin{array}{c}\text { Тюменская }\left(\mathrm{J}_{2}\right) \mathrm{tm}, \\
\mathrm{O}_{2} \text { Tyumen }\end{array}$ & 200,73 & 7,61 & 0,38 & 7,83 & 15,44 & 2,40 \\
\hline 11, песч./sandstone & tm, $Ю_{2}$ & 111,76 & 4,40 & 0,20 & 3,31 & 7,71 & 3,83 \\
\hline \multicolumn{8}{|c|}{ Площадь Южно-Чистинная, скважина 511/Chistinnoe South, well 511} \\
\hline 1, аргиллит/argillite & $\begin{array}{c}\text { Георгиевская }\left(\mathrm{J}_{2}\right) \mathrm{gr} \\
\text { Georgiev }\end{array}$ & 1200,25 & 80,33 & 5,47 & 14,69 & 95,02 & 1,44 \\
\hline 2, песчаник/andstone & $\begin{array}{c}\text { Васюганская }\left(\mathrm{J}_{2}\right) \text { vs, } \\
Ю_{1} \text { Vasyugan }\end{array}$ & 180,64 & 0,29 & 0,01 & 0,03 & 0,32 & 1,18 \\
\hline 3, аргиллит/argillite & vs, $Ю_{1}$ & 238,16 & 4,93 & 0,19 & 4,38 & 9,31 & 1,66 \\
\hline
\end{tabular}




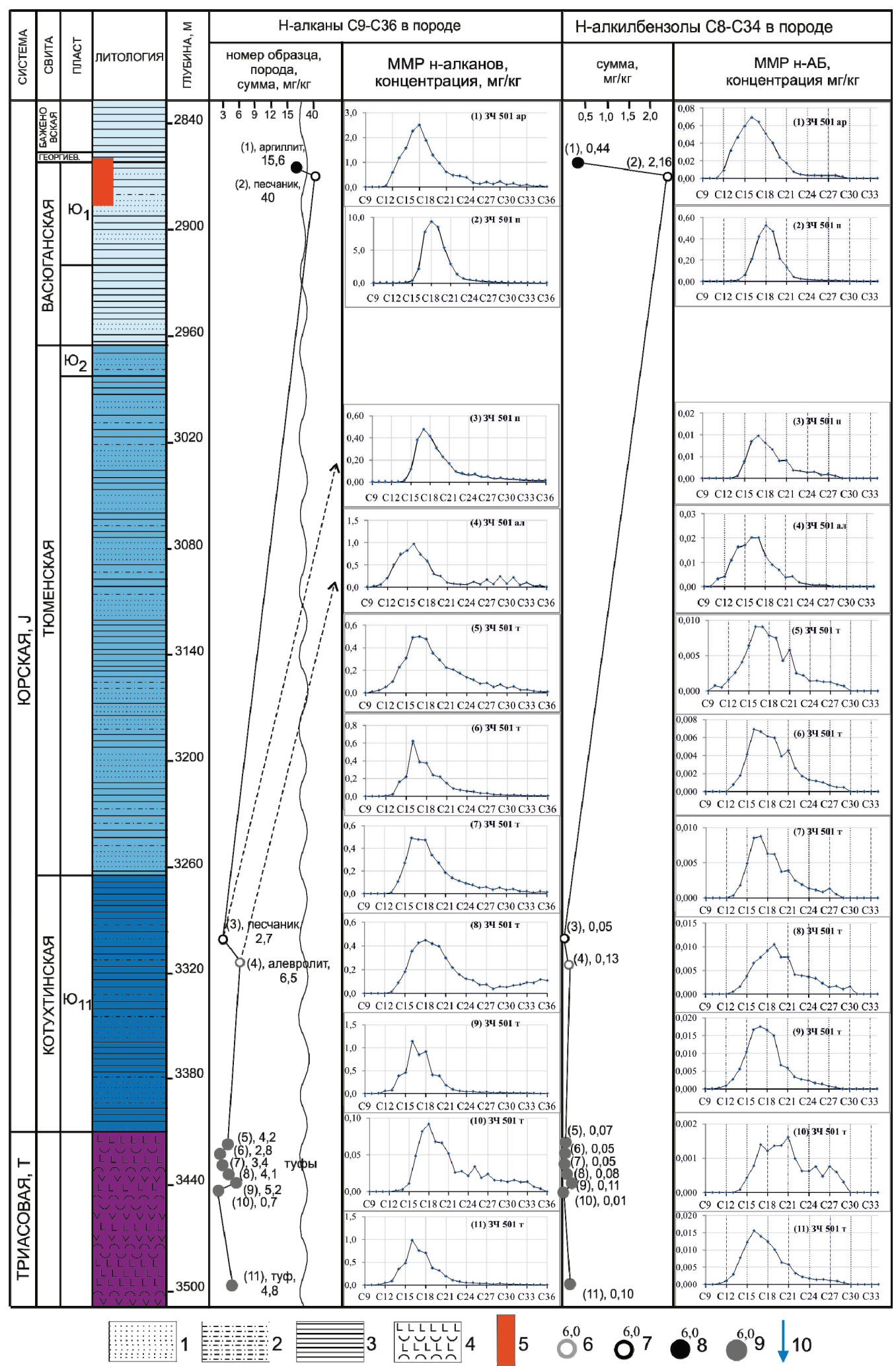

Рис. 3. Скважина Западно-Чистинная 501. Содержание и молекулярно-массовые распределения алкановых и ароматических УВ в разрезе юрских и триасовых отложений: 1 - песчаник; 2 - алевролит; 3 - аргиллит; 4 - породы фундамента; 5 - нефтепроявление; 6 - песчаник, концентрация (мг/кг); 7 - алевролит, кониентрация; 8 - аргиллит, концентрация; 9 - туфыы, концентраиия; 10 - вероятное направление миграции УВ

Fig. 3. Well 501 Chistinnoe West. Contents and molecular mass distribution of n-alkanes and n-alkylbenzenes in Jurassic and Triassic sediments: 1 - sandstone; 2 - siltstone; 3 - argillite; 4 - basement rocks; 5 - oil show; 6 - sandstone, concentration ( $\mathrm{mg} / \mathrm{kg}) ; 7$ - siltstone, concentration; 8 - argillite, concentration; 9 - tuffs, concentration; 10 - possible direction of migration of hydrocarbons 


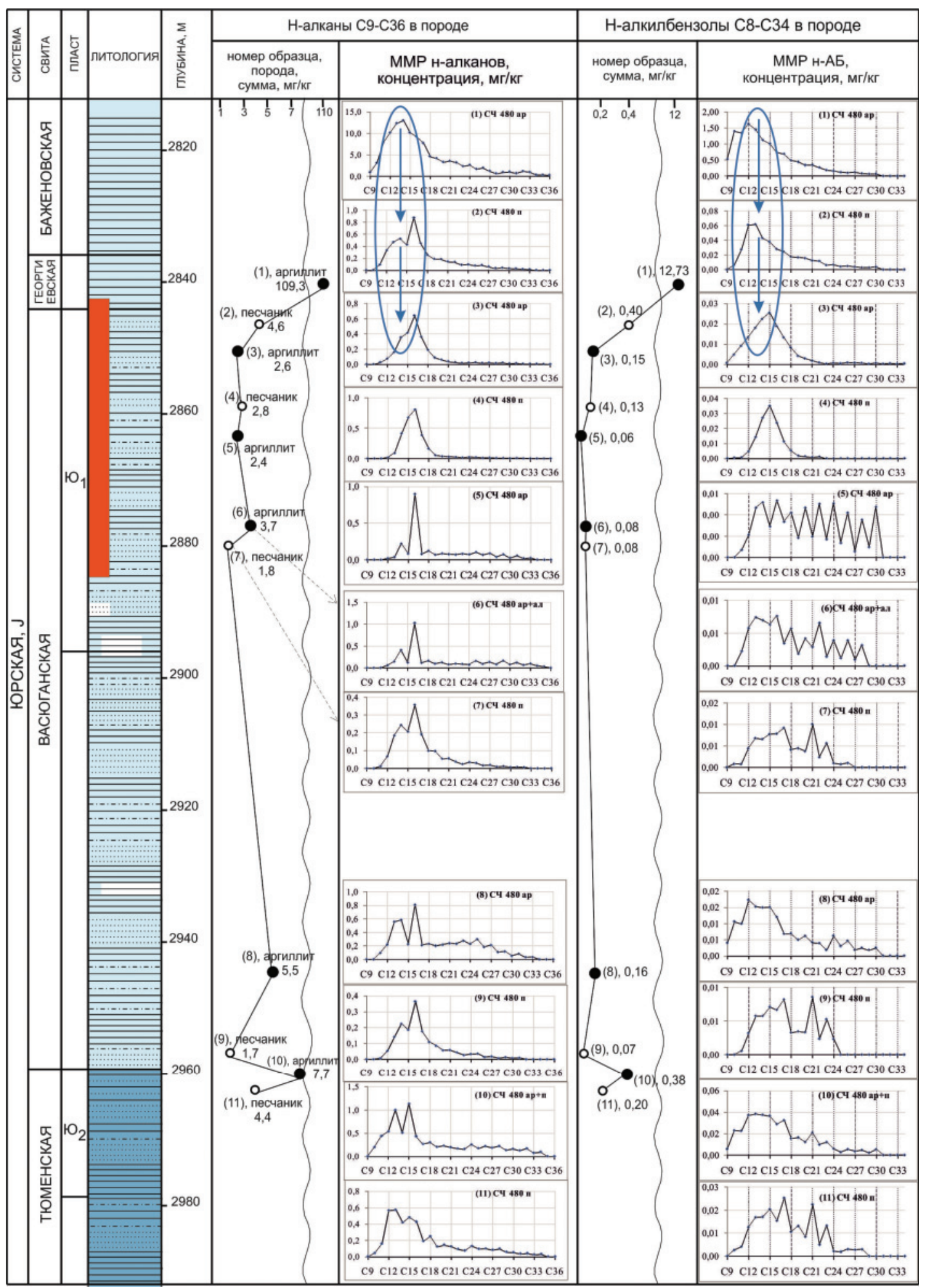

Рис. 4. Скважина Северо-Чистинная 480. Содержание и молекулярно-массовые распределения алкановых и ароматических УВ в разрезе юрских отложений. Условные те же, что на рис. 3

Fig. 4. Well 480 Chistinnoe North. Content and molecular mass distributions of n-alkanes and $n$-alkylbenzenes in the Jurassic sediments. The legend is the same as in Fig. 3

угольных толщ и, возможно, является местной особенностью осадконакопления. Интересно отметить, что для фоновой скважины Южно-Чистин- ной 511 аргиллиты васюганской свиты также содержат органическое вещество с повышенной концентрацией ароматических. 
MМР н-алканов и н-алкилбензолов в юрской зоне нефтепроявления (верх васюганской и георгиевская свиты) имеет в основном унимодальный характер с преобладанием легких гомологов $\mathrm{C}_{9-21}$. В составе н-алканов васюганской и частично тюменской свит резко «выстреливает» концентрация гомолога $\mathrm{C}_{16}$ (иногда и $\mathrm{C}_{14}$ ), а в составе н-алкилбензолов $-\mathrm{C}_{17}, \mathrm{C}_{21}, \mathrm{C}_{23}$ (рис. 4). Эта особенность прослеживается по юрским слоям, затухая в георгиевской свите в верхней части и в котухтинской свите в нижней части разреза, что указывает на существование достаточно свободных внутри и межпластовых перетоков в пределах тюменской и васюганской свит.

В породе георгиевской свиты вид ММР н-алканов и н-алкилбензолов резко отличается от нижележащих отложений. Вероятным источником углеводородов георгиевской свиты является примыкающая к ней баженовская толща. Поток УВ, эмигрирующих из баженовских глин, достаточно высок, чтобы обеспечить насыщение аргиллитов георгиевской свиты примерно на $15 . .20$ м вниз по разрезу (до песчаника 2 СЧ480) и насытить песчаники углеводородами характерного нефтяного состава (рис. 4, овальный контур с указателями перетоков).

В «фоновых» образцах скважины Южно-Чистинной 511 распределение углеводородов в слоях пород практически повторяет наблюдаемое в продуктивной скважине Северо-Чистинной 480 . Концентрации низки, за исключением георгиевской свиты, а ММР н-алканов и н-алкилбензолов широкие $\left(\mathrm{C}_{9}-\mathrm{C}_{33}\right)$. Нефтепроявление на данном участке исследований не фиксируется, возможно, из-за отсутствия ловушек.

В целом о юрской зоне нефтепроявления можно сказать, что перекрывающая ее баженовская толща богата органическим материалом, но является не единственной нефтелатеринской в пределах Чистинной площади. Углеводороды, генерируемые в баженовской толще, формируют "облик» нефти только в верхах зоны нефтепроявления. Основной разрез васюганской свиты имеет углеводороды ближе по ММР н-алканов и н-алкилбензолов к ОВ аргиллитов низов васюганской и тюменской свит.

Для нижнеюрских отложений (котухтинская свита) и доюрского комплекса (образцы скважины ЗЧ501, таблица, рис. 3) характерны низкие концентрации рассматриваемых УВ - на уровне $0,7 \ldots 7,0$ мг/кг, с преобладанием насыщенных над ароматическими в $20 . .50$ раз. Эта особенность отличает ОВ коры выветривания и фундамента от вышележащих пород, как имеющее самостоятельный генезис. Распределения н-алканов и н-алкилбензолов в пределах котухтинской свиты и пород фундамента практически однотипны, одномодальные, с максимумом на $\mathrm{C}_{15}-\mathrm{C}_{21}$ (рис. 3 ). Значения отношения П/Ф указывают на усиление восстановительных условий накопления ОВ с нарастанием глубины (таблица). Признаков перетоков веществ в нижней части юрского разреза и доюрском комплексе, как это отмечено в пределах баженовской и георгиевской свит по ММР н-алканов и н-алкилбензолов, не зафиксировано. Межслойная миграция из фундамента в кору выветривания и котухтинскую свиту возможна в виде малодебитного диффузионного перемещения молекул. Образование залежей маловероятно.

\section{Геохимическая модель вертикальной миграции Ув}

В результате изучения послойного распределения миграционно способных нефтяных углеводородов в породах юрского и доюрского разреза Чистинной группы месторождений составлена геохимическая модель меж- и внутрипластовой вертикальной миграции УВ (рис. 5).

В этой модели можно отметить следующее.

1. В юрской зоне нефтепроявления по составу налканов и н-алкилбензолов фиксируются внутри- и межпластовые перетоки нефти в пределах тюменской и васюганской свит. Вышележащие георгиевские аргиллиты богаты углеводородами, вероятно, производимыми ОВ баженовской свиты и отличающимися по составу от нижележащих слоев. Насыщающие георгиевскую свиту углеводороды, за счет высокой разницы концентраций, диффундируют в нижележащие песчаники верхней подсвиты васюганской свиты, что прослеживается на 20 м по насыщенным и на 10 м по ароматическим УВ.

2. Особенностью углеводородов аргиллитов нижневасюганской и тюменской свит является высокая концентрация ароматических, сравнимая с концентрацией насыщенных УВ. Повышенные концентрации ароматических характерны также для аргиллитов и фоновой скважины ЮЧ511. Высокое содержание ароматических в составе характерно для континентальных угольных толщ и, возможно, является местной особенностью осадконакопления.

3. Органическое вещество триасового комплекса и низов юрского разреза с большой вероятностью не участвовало в образовании запасов углеводородов в васюганской свите (пласт $Ю_{1}{ }^{1}$ ). Молекулярный и групповой состав углеводородов данного интервала имеет свои характерные особенности (превышение доли насыщенных УВ над ароматическими в $20 . . .50$ раз), отличающие его от ОВ вышележащих отложений и не смешивающиеся с ним.

4. Геохимическая модель межпластовой миграции УВ показывает, что в пределах Чистинного участка возможность образования залежей в коллекторах юрского и доюрского комплекса определяется материнским потенциалом и условиями вхождения в главную фазу нефтеобразования «основного источника» углеводородов - юрских аргиллитов баженовской, васюганской и тюменской свит. Второй возможный источник углеводородов - плотные породы триасового и нижележащего палеозойского 


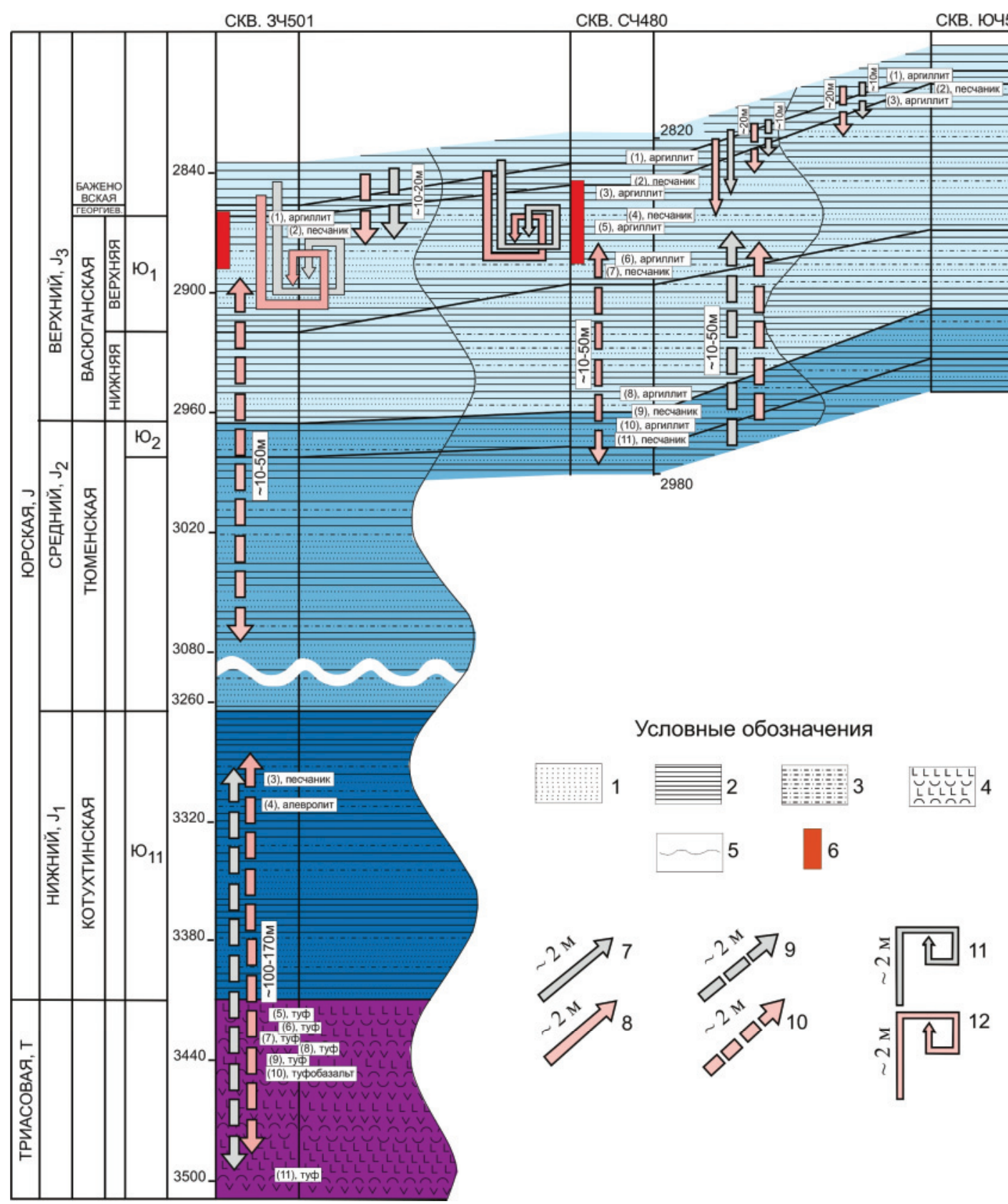

Pис. 5. Чистинная группа нефтяных месторождений (рифтогенный участок ЗСП). Геохилическая модель вертикальной миграции УВ в разрезе юрского и триасового комплексов: 1 - песчаник, 2 - аргиллит, 3 - алевролит, 4 - туф, 5 - интервал отсутствия керна, 6 - нефтепроявления; межпластовая фильтрация, расстояние (м): 7 - насыщенные углеводороды, 8 - аролатические; межпластовая диффузия, расстояние (м): 9 - насыщенные, 10 - ароматические; внутрипластовая миграция, расстояние (м): 11 - насыщенные, 12 - ароматические

Fig. 5. Chistina group of oil fields (rifting phase ZSP). Geochemical model of vertical migration of hydrocarbons in the Jurassic and Triassic complexes: 1 - sandstone, 2 - argillite, 3 - siltstone, 4 - tuff, 5 - lack of a core, 6 - oil show; interlayer filtering, distance $(\mathrm{m}): 7$ - alkanes, 8 - arenes; interlayer diffusion, distance $(m): 9$ - alkanes, 10 - arenes; intralayer migration, distance $(m)$ : 11 - alkanes, 12 arenes

комплекса - имеет низкое содержание ОВ и при благоприятных условиях позволяет утвердить его в качестве второстепенного.

\section{Выводы}

Юрский источник углеводородов в пределах Чистинной группы месторождений может быть утвержден в качестве "основного источника» на основе следующих положений, обоснованных экспериментально установленными фактами.

1. На Чистинном участке нефтеносность связана с верхнеюрским и неокомским клиноформным НГК, в доюрском комплексе индивидуально идентифицированных залежей пока не обнаружено. 
2. Залежь основного нефтеносного объекта - васюганской свиты (пласт $Ю_{1}^{1}$ ) - формируется в результате миграции углеводородов из аргиллитов баженовской и георгиевской свит. Зафиксирован подток дополнительных порций УВ характерного ароматического состава из нижележащих пород тюменской и васюганской свит.

3. Для низов юрских отложений (котухтинская свита) и доюрского комплекса характерно низкое содержание подвижного органического материала и характерный «насыщенный» групповой состав углеводородов. Органическое вещество фундамента и низов юрского разреза с большой вероятностью не участвовало в образовании выявленных запасов углеводородов в васюганской свите.

4. Триасовые вулканиты основного состава в пределах Чистинного участка неблагоприятны для образования резервуаров УВ. Миндалины и трещины залечены вторичными минералами из-за развитых гидротермальных процессов и отсутствия сколько-нибудь значилой разрывной тектоники, свободного порового пространства не фиксируется.

В рассматриваемой зоне закрытого континентального рифта реализуется классический режим

\section{СПИСОК ЛИТЕРАТУРЫ}

1. Kontorovich V.A. Petroleum potential of reservoirs at the Paleozoic-Mesozoic boundary in West Siberia: seismogeological criteria (example of the Chuzik-Chizhapka regional oil-gas accumulation) // Russian Geology and Geophysics. - 2007. - V. 48. № 5. - P. 422-428.

2. Koveshnikov A.E., Nesterova A.C., Dolgaya T.F. Fracture system influence on the reservoirs rock formation of OrdovicianDevonian carbonates in West Siberia tectonic depression // IOP Conference Series: Earth and Environmental Science. - 2016. V. 43. URL: http://earchive.tpu.ru/bitstream/11683/35185/1/ dx.doi.org-10.1088-1755-1315-43-1-012008.pdf (дата обращения 27.05.2019).

3. Brekhuntsov A.M., Monastyrev B.V., Nesterov I.I. (Jr.) Distribution patterns of oil and gas accumulations in West Siberia // Russian Geology and Geophysics. - 2011. - V. 52. - № 8. P. 781-791.

4. Мегакомплексы и структура земной коры Западно-Сибирской плиты / В.С. Сурков, А.А. Трофимук, О.Г. Жеро, Л.В. Смирнов, А.Э. Конторович, Б.А. Канарейкин, Е.В. Карус, В.М. Ковылин, В.Н. Крамник, А.Л. Рудницкий, А.Н. Страхов, А.В. Егоркин, Н.М. Чернышов. - М.: Недра, 1986. - 149 с.

5. Исаев Г.Д. Геология и тектоника палеозоя Западно-Сибирской плиты // Литосфера. - 2010. - № 4. - С. 52-68.

6. Астафьев Д.А., Скоробогатов В.А., Радчикова А.М. Грабенрифтовая система и размещение зон нефтегазонакопления на Севере Западной Сибири // Геология нефти и газа. - 2008. № 4. - C. 2-8.

7. Гаврилов В.П. Геодинамическая модель нефтегазоносности Западной Сибири // Геология нефти и газа. - 2012. - № 2. - С. 60-64.

8. Dobretsov N.L., Shatskiy A.F. Deep carbon cycle and deep geody namics: the role of the core and carbonatite melts in the lower mantle // Russian Geology and Geophysics. - 2012. - V. 53. № 11. - P. 1117-1132.

9. Uzon volcano caldera (Kamchatka): a unique natural laboratory of the present-day naphthide genesis / A.E. Kontorovich, нефтегазообразования, с наложением незначительного притока легких углеводородов из фундамента. Последнее возможно по механизму глубинного цикла «абиогенного» углерода [12]. Наиболее вероятно заполнение верхнеюрских и меловых ловушек.

Таким образом, в отличие от областей устойчивого погружения кристаллических массивов [24], в пределах рифтовых зон прогноз заполнения ловушек коры выветривания и фундамента из вышележащего «юрского источника» менее вероятен. Залежи нефти в доюрском основании в пределах рифтовых зон могут сформироваться из ОВ палеозойского генезиса, при наличии условий образования резервуаров в породах фундамента и коры выветривания. Однако ожидаемые залежи могут быть низко дебитными, мелкими по запасам.

Конечно, сформулированные выше выводы 0 генезисе залежей УВ в пределах рифтовых зон, впрочем, как и в пределах кристаллических массивов, имеют прогнозный характер. Необходимо подтверждение этих выводов исследованиями на других месторождениях. Важно выполнить аналогичные исследования в иных структурно-формационных зонах Западной Сибири. Интересны антиклинорные зоны инверсионного типа развития палеозойские осадочные бассейны.

S.B., Bortnikova G.A. Karpov, V.A. Kashirtsev, E.A. Kostyreva, A.N. Fomin // Russian Geology and Geophysics. - 2011. V. 52. - № 8. - P. 768-772.

10. Kontorovich A.E. I.M. Gubkin's paradigm of the development of the USSR oil industry in the 20th century / Russian Geology and Geophysics. - 2017. - V. 58. - № 3-4. - P. 283-293.

11. Тимурзиев А.И. Альтернативы «сланцевого» сценария развития ТЭК России на основе глубинной парадигмы нефтегазовой геологии // Геофизический журнал. - 2018. - Т. 40. - № 4. C. $133-154$.

12. Сорохтин Н.О., Лобковский Л.И., Семилетов И.П. Глубинный цикл углерода и формирование абиогенных углеводородов // Известия Томского политехнического университета. Инжиниринг георесурсов. - 2018. - Т. 329. - № 8. - С. 156-173.

13. Dmitrievskii A.N. Polygenesis of Oil and Gas // Doklady Earth Sciences. - 2008. - V. 419. - № 2. - P. 373-377.

14. Тяпкина А.Н., Тяпкин Ю.К. Синхронная сейсмическая инверсия для выявления перспективных участков в карбонатных породах юго-восточной части Западно-Сибирской платформы // Геофизический журнал. - 2019. - Т. 41. - № 1. - С. 76-94.

15. Исаев Г.Д., Аухатов Я.Г. Прогноз нефтегазоносности палеозоя с новых концептуальных позиций // Пути реализации нефтегазового потенциала Ханты-Мансийского автономного округаЮгры. Т. 1. - Ханты-Мансийск: ИздатНаукаСервис, 2006. C. $113-121$.

16. Нефтегазоносность коллекторов коры выветривания и палеозоя юго-востока Западной Сибири (прогнозирование трудноизвлекаемых запасов) / Г.А. Лобова, В.И. Исаев, С.Г. Кузьменков, Т.Е. Лунёва, Е.Н. Осипова // Геофизический журнал. 2018. - T. 40. - № 4. - С. 73-106.

17. Лобова Г.А., Лунёва Т.Е., Кириллина М.С. Районирование перспектив нефтегазоносности доюрских резервуаров Нюрольской мегавпадины (по данным палеотемпературного моделирования и бурения) // Известия Томского политехнического университета. Инжиниринг георесурсов, - 2018. - Т. 329. - № 3. C. $123-133$. 
18. Прогноз нефтегазоносности в зонах дезинтеграции доюрского фундамента на Сургутском своде и прилегающих территориях / Н.Я. Медведев, И.М. Кос, А.И. Ларичев, Л.В. Смирнов, 0.И. Бостриков, А.С. Фомичев // Пути реализации нефтегазового и рудного потенциала Ханты-Мансийского автономного округа-Югры. Т. 1. - Ханты-Мансийск: ИздатНаукаСервис, 2007. - C. 189-196.

19. Gogonenkov G.N., Timurziev A.I. Strike-slip faulting in the West Siberian Platform: Insights from 3D seismic imagery // Comptes Rendus Geoscience. - 2012. - V. 344. - № 3-4. P. 214-226.

20. Catagenesis of organic matter at the top and base of the Jurassic complex in the West Siberian megabasin / A.E. Kontorovich, A.N. Fomin, V.0. Krasavchikov, A.V. Istomin // Russian Geology and Geophysics. - 2009. - V. 50. - № 11. - P. 917-929.

21. Стратегия и основы технологии поисков углеводородов в доюрском основании Западной Сибири / В.И. Исаев, Г.А. Лобова, Ю.В. Коржов, М.Я. Кузина, Л.К. Кудряшова, О.Г. Сунгурова. - Томск: Изд-во Томского политехнического университета, 2014. - $112 \mathrm{c}$.

22. Aryl isoprenoids in crude oils of the Nyurol'ka depression (southeast of Western Siberia) / D.Yu. Chirkova, N.A. Krasnoyarova, 0.V. Serebrennikova, Ya.V. Olenev // Petroleum Chemistry. - 2017. - V. 57. - № 1. - P. 54-59.

23. Saltymakova D., Krasnoyarova N., Serebrennikova 0. Distinct features of crude oils from Nyurol'ka Depression (Southeast of Western Siberia) // Journal of Petroleum Science and Engineering. - 2017. - V. 154. - P. 91-99.

24. Генезис доюрских залежей нефти Рогожниковской группы месторождений (по результатам изучения вертикальной зональности алканов) / Ю.В. Коржов, В.И. Исаев, М.Я. Кузина, Г.А. Лобова // Известия Томского политехнического университета. - 2013. - Т. 323. - № 1. - С. 51-56.

25. Распределение ароматических углеводородов в разрезе отложений нефтегазоносных комплексов (на примере месторождений Красноленинского свода) / Ю.В. Коржов, В.И. Исаев, А.А. Жильцова, О.В. Латыпова // Геофизический журнал. 2013. - T. 35. - № 1. - C. 113-129.

26. Сурков В.С., Жеро О.Г. Фундамент и развитие платформенного чехла Западно-Сибирской плиты. - М.: Недра, 1981. - 143 с.

27. Belitskaya E.A., Serebrennikova O.V., Kadychagov P.B. Crude oils from the Koltogor rift and adjacent areas (West Siberia): Specifics of the composition of aromatic compounds // Petroleum Chemistry. - 2008. - V. 48. - № 4. - P. 260-268.

28. Belitskaya E.A., Serebrennikova 0.V. Crude oils from the Koltogor rift and adjacent areas (West Siberia): Specifics of the compo sition of biomarkers // Petroleum Chemistry. - 2009. - V. 49. № 6. - P. 458-465.
29. Dray E.E., Evans E.D. Distribution of n-paraffins as a clue to recognition of source beds // Geochimica et Cosmochimica Acta. 1961. - V. 22. - P. 2-15.

30. Korzhov Yu.V., Krasnoyarova N.A., Golovko A.K. Potential usefulness of alkylbenzenes and alkylnaphthalenes compositions parameters for oil-oil korrelation // 17-th International Meeting of Organic Geochemistry. - San-Sebastian Donostia, September 1995. - Spain: Sans-Sebastian, 1995. - P. 433-434.

31. Атлас «Геология и нефтегазоносность Ханты-Мансийского автономного округа" / под ред. Э.А. Ахпателова, В.А. Волкова, В.Н. Гончаровой, В.Г. Елисеева, В.И. Карасева, А.Г. Мухер, Г.П. Мясниковой, Е.А. Теплякова, Ф.З. Хафизова, А.В. Шпильмана, В.М. Южаковой. - Екатеринбург: Изд-во «ИздатНаукаСервис», 2004. - 148 с.

32. Проблемы поиска и картирования ловушек углеводородов в доюрском комплексе Широтного приобья (территория деятельности 000 «Лукойл - Западная Сибирь) / Л.А. Задоенко, 0.А. Нигматзянова, А.Н. Задоенко, И.С. Муртаев // Фундамент, структуры обрамления Западно-Сибирского мезозойско-кайнозойского осадочного бассейна, их геодинамическая эволюция и проблемы нефтегазоносности: Всероссийская научная конференция. Сборник докладов / науч. ред. А.Э. Конторович, А.М. Брехунцов. Тюмень-Новосибирск: 000 «Параллель», 2008. - С. 82-88.

33. Иванова Л.И., Исаев В.И., Коржов Ю.В. Методика лабораторных исследований тяжелых углеводородов при нефтепоисковой геохимии // Изменяющаяся геологическая среда: пространственно-временные взаимодействия эндогенных и экзогенных процессов: Матер. Междунар. конф. - Казань, 12-16 ноября 2007. - Казань: Изд-во «Фэн», 2007. - С. 356-360.

34. Гончаров И.В. Геохимия нефтей Западной Сибири. - М.: Недра, 1987. - 179 с

35. Pevneva G.S., Golovko A.K. Geochemical Characterization of Organic Matter from the Middle Jurassic Sediments of Western Siberia on the Basis of the Composition of Alkylaromatic Hydrocarbons // Geochemistry International. - 2012. - V. 50 - № 1. - P. 74-83.

36. Summons R.E., Powell T.G. Identication of aryl isoprenoids in source rocks and crude oils: biological markers for the green sulphur bacteria // Geochim. Cosmochim. Acta. - 1987. - V. 51. - P. 557-566.

37. Peters K., Moldowan J. The Biomarker Guide: Interpreting Molecular Fossils in Petroleum and Ancient Sediments. - Englewood Cliffs: Prentice Hall, 1992. - 363 p.

38. Goncharov I.V., Oblasov N.V. Regularities of changes in fluid composition and properties in Vankor field pools: from light to heavy oil // IOP Conference Series: Earth and Environmental Science. - 2015. - V. 24. URL: http://dx.doi.org/10.1088/ 1755-1315/24/1/012039 (дата обращения 27.05.2019).

Поступила 14.07.2019 2.

\section{Информация об авторах}

Коржов Ю.В., кандидат химических наук, доцент Института нефти и газа Югорского государственного университета.

Лобова $\boldsymbol{\Gamma} . \boldsymbol{A . ,}$ доктор геолого-минералогических наук, профессор Отделения геологии Инженерной школы природных ресурсов Национального исследовательского Томского политехнического университета.

Исаев В.И., доктор геолого-минералогических наук, профессор Отделения геологии Инженерной школы природных ресурсов Национального исследовательского Томского политехнического университета; ведущий научный сотрудник Института нефти и газа Югорского государственного университета.

Стариков А.И., кандидат технических наук, доцент Института нефти и газа Югорского государственного университета.

Кузина M.Я., старший преподаватель Института нефти и газа Югорского государственного университета.

Орлов C.A., кандидат физико-математических наук, доцент Института нефти и газа Югорского государственного университета. 
UDC 553.98;550.4:571.12

\title{
GENESIS OF HYDROCARBONS OF JURASSIC AND PRE-JURASSIC COMPLEXES OF CHISTINNOE FIELD (KOLTOGORSK URENGOY PALEORIFT AREA)
}

\author{
Yuriy V. Korzhov', \\ ykor1962@mail.ru
}

Galina A. Lobova²,

Valeriy I. Isaev ${ }^{2,1}$, isaevvi@tpu.ru

\section{Andrey I. Starikov', \\ a_starikov@ugrasu.ru}

\author{
Marina Ya. Kuzina', \\ m_kuzina@ugrasu.ru
}

\author{
Sergey A. Orlov', \\ yunitov@mail.ru \\ 1 Yugra State University, \\ 16, Chekhov street, Khanty-Mansiysk, 628011, Russia. \\ ${ }^{2}$ National Research Tomsk Polytechnic University, \\ 30, Lenin Avenue, Tomsk, 634050, Russia.
}

The genesis of hydrocarbons in the Jurassic and pre-Jurassic complexes of the Chistinnoe group of oil fields located in the KoltogorskUrengoy paleorift zone is determined. The research is relevant to substantiate the strategy of searching for oil and gas deposits, taking into account the tectonics of the basement of the West siberian plate.

The aim of the research is to determine the «main source» of hydrocarbons of Jurassic and pre-Jurassic horizons in the rift zones of the basement.

Objects and methods. The core of Jurassic and pre-Jurassic complexes of productive and non-productive wells of the Chistinnoe group of fields of the Vartovsky oil and gas area is studied. Lithological and petrographic characteristics were determined using optical microscopy. The content of mobile hydrocarbons in the rock, including the series of $n$-alkanes, $n$-alkylbenzenes, components of the series of naphthalene and phenanthrene was determined by methods of organic geochemistry, chromatography and mass spectrometry.

Results and conclusions. The authors have constructed the geochemical model of inter-and intra-layer migration of hydrocarbons. Hydrocarbon composition of the upper part of the Jurassic section indicates that the oil deposits in the Vasyugan formation (stratum Y Y ${ }_{1}^{i}$ ) were formed as a result of emigration of hydrocarbons from the shales of the Bazhenov and Georgiev formations. The organic substance of the basement and bottom rocks of the Jurassic section differs from the overlying sediments in molecular and group composition of hydrocarbons and probably did not participate in filling the upper Jurassic traps. Triassic volcanics are not favorable for formation of hydrocarbon reservoirs, voids are filled with secondary minerals due to developed hydrothermal processes and the lack of significant disjunctive tectonics, the forecast of filling the weathering crust traps from the overlying "Jurassic source» is unlikely. The organic substance of Paleozoic genesis may form small deposits in the pre-Jurassic base. In the area of the continental paleorift depression the classic mode of petroleum formation is implemented.

\section{Key words:}

Jurassic and pre-Jurassic complexes, lithology, "main source» of hydrocarbons, optical microscopy and methods of organic geochemistry, geochemical model of migration and accumulation of hydrocarbons in riftogenic zones of the West Siberian plate.

\section{REFERENCES}

1. Kontorovich V.A. Petroleum potential of reservoirs at the Paleozoic-Mesozoic boundary in West Siberia: seismogeological criteria (example of the Chuzik-Chizhapka regional oil-gas accumulation). Russian Geology and Geophysics, 2007, vol. 48, no. 5, pp. 422-428.

2. Koveshnikov A.E., Nesterova A.C., Dolgaya T.F. Fracture system influence on the reservoirs rock formation of OrdovicianDevonian carbonates in West Siberia tectonic depression. IOP Conference Series: Earth and Environmental Science, 2016, vol. 43. Available at: http://earchive.tpu.ru/bitstream/11683/ 35185/1/dx.doi.org-10.1088-1755-1315-43-1-012008.pdf/ (accessed 27 May 2019).

3. Brekhuntsov A.M., Monastyrev B.V., Nesterov I.I. (Jr.) Distribution patterns of oil and gas accumulations in West Siberia. Russian Geology and Geophysics, 2011, vol. 52, no. 8, pp. 781-791.

4. Surkov V.S., Trofimuk A.A., Zhero 0.G., Smirnov L.V., Kontorovich A.E., Kanareikin B.A., Karus E.V., Kovylin V.M., Kramnik V.N., Rudnicki A.L., Strakhov A.N., Egorkin A.V., Chernyshov N.M. Megakompleksy i stroyenie zemnoy kory ZapadnoSibirskoy plity [Megacomplexes and structure of the earth's crust of the West Siberian plate]. Moscow, Nedra Publ., 1986. 149 p. 
5. Isaev G.D. Geology and tectonics of the Paleozoic of the West Siberian plate. Lithosphere, 2010, no. 4, pp. 52-68. In Rus.

6. Astafiev D.A., Skorobogatov V.A., Radchikova A.M. Graben-rift system and location of oil and gas accumulation zones in the North of Western Siberia. Oil and gas geology, 2008, no. 4, pp. 2-8. In Rus.

7. Gavrilov V.P. Geodynamic model of oil and gas potential of Western Siberia. Oil and gas geology, 2012, no. 2, pp. 60-64. In Rus.

8. Dobretsov N.L., Shatskiy A.F. Deep carbon cycle and deep geodynamics: the role of the core and carbonatite melts in the lower mantle. Russian Geology and Geophysics, 2012, vol. 53, no. 11, pp. 1117-1132.

9. Kontorovich A.E., Bortnikova S.B., Karpov G.A., Kashirtsev V.A., Kostyreva E.A., Fomin A.N. Uzon volcano caldera (Kamchatka): a unique natural laboratory of the present-day naphthide genesis. Russian Geology and Geophysics, 2011, vol. 52, no. 8, pp. 768-772.

10. Kontorovich A.E. I.M. Gubkin's paradigm of the development of the USSR oil industry in the 20th century. Russian Geology and Geophysics, 2017, vol. 58, no. 3-4, pp. 283-293.

11. Timurziev A.I. Alternatives of «shale scenario» of development of the Russian fuel and energy complex on the basis of the deep oil paradigm of petroleum geology. Geophysical journal, 2018, vol. 40, no. 4, pp. 133-154. In Rus.

12. Sorokhtin N.0., Lobkovsky L.I., Semiletov I.P. Deep carbon cycle and formation of abiogenic hydrocarbons. Bulletin of the Tomsk Polytechnic University. Geo Assets Engineering, 2018, vol. 329, no. 8, pp. 156-173. In Rus.

13. Dmitrievskii A.N. Polygenesis of Oil and Gas. Doklady Earth Sciences, 2008, vol. 419, no. 2, pp. 373-377.

14. Tyapkina A.N., Tyapkin Yu.K. Synchronous seismic inversion to identify promising areas in carbonate rocks of the South-Eastern part of the West Siberian platform. Geophysical journal, 2019, vol. 41, no. 1, pp. 76-94. In Rus.

15. Isaev G.D., Aujatov Ya.G. Prognoz neftegazonosnosti paleozoya s novykh kontseptualnykh pozitsiy [Forecast of Paleozoic oil and gas potential from new conceptual positions]. Puti realizatsii nef tegazovogo potentsiala Khanty-Mansiyskogo avtonomnogo okruga-Yugry [Ways of realization of oil and gas potential of KhantyMansiysk Autonomous Okrug-Yugra]. Vol. 1ю Khanty-Mansiysk, IzdatNaukaServis Publ., 2006. pp. 113-121.

16. Lobova G.A., Isaev V.I., Kuzmenkov S.G., Luneva T.E., Osipova E.N. Oil and gas potential of weathering crust and Paleozoic reservoirs in the South-East of Western Siberia (prediction of hard-to-recover reserves). Geophysical journal, 2018, vol. 40, no. 4, pp. 73-106. In Rus.

17. Lobova G.A., Luneva T.E., Kirilina M.S. Zoning of oil-gas potential of pre-Jurassic reservoirs in Nyurol'ka megadepression (using paleotemperature modeling and drilling). Bulletin of the Tomsk Polytechnic University. Geo Assets Engineering, 2018, vol. 329, no. 3, pp. 123-133. In Rus.

18. Medvedev N.Ya., Kos I.M., Larichev A.I., Smirnov L.V., Bostrikov 0.I., Fomichev A.S. Prognoz neftegazonosnosti v zonakh dezintegratsii doyurskogo fundamenta na Surgutskom svode i prilegayushchikh territoriyakh [Forecast of oil and gas potential in the areas of disintegration of the pre-Jurassic basement in the Surgut arch and adjacent territories]. Puti realizatsii neftegazovogo potentsiala Khanty-Mansiyskogo avtonomnogo okruga-Yugry [Ways of realization of oil and gas potential of Khanty-Mansiysk Autonomous Okrug-Yugra]. Vol. 1. Khanty-Mansiysk, IzdatNaukaServis Publ., 2007. pp. 189-196.

19. Gogonenkov G.N., Timurziev A.I. Strike-slip faulting in the West Siberian Platform: Insights from 3D seismic imagery. Com ptes Rendus Geoscience, 2012, vol. 344, no. 3-4, pp. 214-226.

20. Kontorovich A.E., Fomin A.N., Krasavchikov V.O., Istomin A.V. Catagenesis of organic matter at the top and base of the Jurassic complex in the West Siberian megabasin. Russian Geology and Geophysics, 2009, vol. 50, no. 11, pp. 917-929.

21. Isaev V.I., Lobova G.A., Korzhov Yu.V., Kuzina M.Ya., Kudryashova L.., Sungurova 0.G. Strategiya i osnovy tekhnologii poiskov uglevodorodov v doyurskom osnovanii Zapadnoy Sibiri [Strategy and technology basics of searching for hydrocarbons in preJurassic base of Western Siberia]. Tomsk, TPU Publ. house, 2014. $112 \mathrm{p}$.

22. Chirkova D.Yu., Krasnoyarova N.A., Serebrennikova O.V., Olenev Ya.V. Aryl isoprenoids in crude oils of the Nyurol'ka depression (southeast of Western Siberia). Petroleum Chemistry, 2017, vol. 57, no. 1, pp. 54-59.

23. Saltymakova D., Krasnoyarova N., Serebrennikova 0. Distinct features of crude oils from Nyurol'ka Depression (Southeast of Western Siberia). Journal of Petroleum Science and Engineering, 2017, vol. 154, pp. 91-99.

24. Korzhov Yu.V., Isaev V.I., Kuzina M.Ya., Lobova G.A. Genesis of the pre-Jurassic oil deposits of Rogozhnikovsky group of fields (based on the results of the study of the vertical zonality of alkanes). Bulletin of the Tomsk Polytechnic University, 2013, vol. 323, no. 1, pp. 51-56. In Rus.

25. Korzhov Yu.V., Isaev V.I., Zhiltsova A.A., Latypova 0.V. Distribution of aromatic hydrocarbons in the section of deposits of oil and gas complexes (on the example of Krasnoleninsky arch deposits). Geophysical journal, 2013, vol. 35, no. 1, pp. 113-129. In Rus.

26. Surkov V.S., Zhero 0.G. Fundament $i$ razvitie platformennogo chekhla Zapadno-Sibirskoy plity [Basement and development of the platform cover of the West Siberian plate]. Moscow, Nedra Publ., 1981. 143 p.

27. Belitskaya E.A., Serebrennikova O.V., Kadychagov P.B. Crude oils from the Koltogor rift and adjacent areas (West Siberia): Specifics of the composition of aromatic compounds. Petroleum Chemistry, 2008, vol. 48, no. 4, pp. 260-268.

28. Belitskaya E.A., Serebrennikova 0.V. Crude oils from the Koltogor rift and adjacent areas (West Siberia): Specifics of the composition of biomarkers. Petroleum Chemistry, 2009, vol. 49, no. 6, pp. $458-465$.

29. Dray E.E., Evans E.D. Distribution of n-paraffins as a clue to recognition of source beds. Geochimica et Cosmochimica Acta, 1961, vol. 22, pp. 2-15.

30. Korzhov Yu.V., Krasnoyarova N.A., Golovko A.K. Potential usefulness of alkylbenzenes and alkylnaphthalenes compositions parameters for oil-oil correlation. $17^{\text {th }}$ International Meeting of Organic Geochemistry. San-Sebastian Donostia, September 1995. Spain, Sans-Sebastian, 1995. pp. 433-434.

31. Atlas "Geologiya i neftegazonosnost Khanty-Mansiyskogo avtonomnogo okruga» [Atlas «Geology and oil and gas potential of the Khanty-Mansiysk Autonomous Okrug»]. Eds. E.A. Akhpatelov, V.A. Volkov, V.N. Goncharova, V.G. Eliseev, V.I. Karasev, A.G. Mukher, G.P. Myasnikova, E.A. Teplyakov, F.Z. Khafizov, A.V. Shpielmann, V.M. Yuzhakova Ekaterinburg, IzdatNaukaServis Publ., 2004. 148 p.

32. Zadoenko L.A., Nigmatzyanova A.N., Zadoenko A.N., Murtaev I.S. Problemy poiska i kartirovaniya lovushek uglevodorodov v doyurskom komplekse Shirotnogo priobya (territoriya deyatelnosti 000 «Lukoyl - Zapadnaya Sibir) [Problems of search and mapping of hydrocarbon traps in the pre-Jurassic complex of the Latitudinal Ob region (territory of LUKOIL - Western Siberia)]. Fundament, struktury obramleniya Zapadno-Sibirskogo mezozoysko-kaynozoyskogo osadochnogo basseyna, ikh geodinamicheskaya evolyutsiya i problem neftegazonosnosti/Vserossiyskaya nauchnaya konferentsiya. Sbornik dokladov [Basement, framework structures of the West Siberian Mesozoic-Cenozoic sedimentary basin, their geodynamic evolution and problems of oil and gas potential. All-Russian scientific conference. Conference 
Proceedings]. Eds. A.E. Kontorovich, A.M. Brekhuntsov. Tyumen-Novosibirsk, 000 «Parallel» Publ., 2008. pp. 82-88.

33. Ivanova L.I., Isaev V.I., Korzhov Yu.V. Metodika laboratornykh issledovaniy tyazhelykh uglevodorodov pri neftepoiskovoy geokhimii [Methods of laboratory studies of heavy hydrocarbons in oil exploration geochemistry]. Izmenyayushchayasya geolo gicheskaya sreda: prostranstvenno-vremennye vzaimodeystviya endogennykh i ekzogennykh protsessov. Materialy Mezhdunarodnoy konferentsii [Changing geological environment: space-time interactions of endogenous and exogenous processes: Proc. of International Conf.]. Kazan, 12-16 November 2007. Kazan, Feng Publ. house, 2007. pp. 356-360.

34. Goncharov I.V. Geokhimiya neftey Zapadnoy Sibiri [Geochemistry of oils of Western Siberia]. Moscow, Nedra Publ., 1987. $179 \mathrm{p}$.

35. Pevneva G.S., Golovko A.K. Geochemical Characterization of Organic Matter from the Middle Jurassic Sediments of Western Si-

\section{Information about the authors}

Yuriy V. Korzhov, Cand. Sc., associate professor, Yugra State University.

Galina A. Lobova, Dr. Sc., professor, National Research Tomsk Polytechnic University.

Valeriy I. Isaev, Dr. Sc., professor, National Research Tomsk Polytechnic University; leading researcher, Yugra State University.

Andrey I. Starikov, Cand. Sc., associate professor, Yugra State University.

Marina Ya. Kuzina, senior lecturer, Yugra State University.

Sergey A. Orlov, Cand. Sc., associate professor, Yugra State University. beria on the Basis of the Composition of Alkylaromatic Hydrocarbons. Geochemistry International, 2012, vol. 50, no. 1, pp. 74-83.

36. Summons R.E., Powell T.G. Identication of aryl isoprenoids in source rocks and crude oils: biological markers for the green sulphur bacteria. Geochim. Cosmochim. Acta, 1987, vol. 51, pp. 557-566.

37. Peters K., Moldowan J. The Biomarker Guide: Interpreting Molecular Fossils in Petroleum and Ancient Sediments. Englewood Cliffs, Prentice Hall, 1992. 363 p.

38. Goncharov I.V., Oblasov N.V. Regularities of changes in fluid composition and properties in Vankor field pools: from light to heavy oil. IOP Conference Series: Earth and Environmental Science, 2015, vol. 24. Available at: http://dx.doi.org/10.1088/ 1755-1315/24/1/012039 (accessed 27 May 2019).

Received: 14 July 2019. 